\title{
Wanted: a Bigger Stick. On Unfair Terms in Consumer Contracts with Online Service Providers
}

\author{
Marco $\operatorname{Loos}^{1} \cdot$ Joasia Luzak ${ }^{1}$
}

Received: 10 December 2014 / Accepted: 18 September 2015 /

Published online: 20 October 2015

(C) The Author(s) 2015. This article is published with open access at Springerlink.com

\begin{abstract}
The Unfair Contract Terms Directive offers consumers protection from preformulated imbalanced contract terms. While the standard terms and conditions of online service providers have previously been accused of harming clients of such online services, a comprehensive analysis of the potential unfair character of such terms and conditions in line with the interpretation of the Directive supplied by the CJEU has not yet been provided. This paper aims to fill in this gap in the academic literature. It identifies several types of contractual terms used by international online service providers in their consumer contracts, which are unlikely to pass the Directive's unfairness test.
\end{abstract}

Keywords Consumer contracts · Unfair contract terms · Online service providers · Compliance · Private international law

The Unfair Contract Terms Directive (the "Directive" or the "UCTD") offers consumers in the European Union protection from pre-formulated imbalanced contract terms (Tenreiro 1995, pp. 278-279). According to the Court of Justice of the European Union (the "CJEU"), the Directive's system of protection assumes that the consumer is in a weak position vis-à-vis the trader as regards both her bargaining power and her level of knowledge. This often leads to the consumer agreeing to terms

${ }^{1}$ Council Directive 93/13/EEC of 5 April 1993 on unfair terms in consumer contracts, OJ 1993, L 095/29.

Marco Loos

m.b.m.loos@uva.nl

Joasia Luzak

j.a.luzak@uva.nl

1 Centre for the Study of European Contract Law, University of Amsterdam, Amsterdam,

The Netherlands 
drawn up in advance by the seller or supplier without being able to influence the content of such terms (Micklitz 2010, pp. 360-361). ${ }^{2}$ The Directive aims to provide for a mechanism ensuring that every contractual term that is not individually negotiated may be reviewed in order to determine whether it is unfair (Tenreiro 1995, pp. 275-276). ${ }^{3}$ The standard terms and conditions used by online service providers have previously been accused of harming clients of such online services (Bradshaw et al. 2011; Rustad and Onufrio 2012; Wauters et al. 2014b). However, to our best knowledge, a comprehensive analysis of the potential unfair character of such terms and conditions in line with the interpretation of the Directive supplied by the CJEU has not yet been provided. ${ }^{4}$ This paper aims to fill in this gap in the academic literature. This paper, therefore, does not challenge the concepts of the Directive but rather extensively exposes terms and conditions of selected online service providers as not complying with existing European legislation. Such terms and conditions could, therefore, be contested in more than one Member State. In our opinion, a coordinated cross-border enforcement could motivate online service providers to change their policies.

We have examined various documents available online to clients of such international online service providers like Google, ${ }^{5}$ Twitter, ${ }^{6}$ Facebook, ${ }^{7}$ and Dropbox ${ }^{8}$ and identified a number of contractual terms that could be submitted to the unfairness test. We have chosen as our subjects these particular online service providers, as they operate throughout the European Union and, therefore, their contract terms should be compliant with applicable European laws. Moreover, they represent various sectors of online services, from e-mail service providers and social networks to cloud-based storage service providers. This allows us to examine whether there is any distinction in the exhibited compliance standard depending on which sector of online services a given service provider is active in. Previous studies of standard contract terms and conditions of online service providers (Bradshaw et al. 2011; Wauters et al. 2014b) did not focus on evaluating the possibility of unfairness of such terms, and, therefore,

\footnotetext{
${ }^{2}$ See for instance CJEU 4 June 2009, case C-243/08, ECLI:EU:C:2009:350 (Pannon), point 22; CJEU 26 April 2012, case C-472/10, ECLI:EU:C:2012:242 (NFH/Invitel), point 33; CJEU 21 March 2013, case C-92/11, ECLI:C:EU:2013:180 (RWE Vertrieb AG/Verbraucherzentrale Nordrhein-Westfalen eV), point 41; CJEU 30 April 2014, case C-26/13, ECLI:EU:C:2014:282 (Kásler and Káslerné Rábai/OTP Jelzálogbank Zrt), point 39.

3 CJEU 21 March 2013, case C-92/11, ECLI:C:EU:2013:180 (RWE Vertrieb AG/Verbraucherzentrale Nordrhein-Westfalen eV), point 42; CJEU 30 April 2014, case C-26/13, ECLI:EU:C:2014:282 (Kásler and Káslerné Rábai/OTP Jelzálogbank Zrt), point 40.

${ }^{4}$ Bradshaw et al. (2011) focus on the specifics of cloud computing contracts; Wauters et al. 2014b specifically target networking sites. Finally, Rustad and Onufrio (2012), who scrutinize the standard terms and conditions of several US online service providers, approach the matter more from the point of view of US companies having to adapt their standard terms and conditions in order to safely export consumer information products to Europe (and elsewhere).

${ }^{5}$ Google Terms of Service are available online at https://www.google.com/intl/en/policies/terms/regional.html (last visited on 7 August 2015). According to this website, Google Terms of Service have last been amended on 30 April 2014.

${ }^{6}$ Twitter's Terms of Service are available online at https://twitter.com/tos (last visited on 7 August 2015). According to this website, the Terms of Service is effective as of 18 May 2015.

${ }^{7}$ Facebook's Statement of Rights and Responsibilities are available online at https://en-gb.facebook.com/legal/ terms (last visited on 7 August 2015). According to a posting on its Site Governance website (available at https:// www.facebook.com/fbsitegovernance, last visited on 7 August 2015), the last changes to Facebook's Statement of Rights and Responsibilities have taken effect on 30 January 2015.

${ }^{8}$ Dropbox Terms of Service are available online at https:/www.dropbox.com/terms?view_en\#terms (last visited on 7 August 2015). According to this website, the Terms of Service have been posted on 1 May 2015.
} 
our paper reveals new arguments that could be raised to claim unenforceability of such clauses.

The following sections first address the issue of the Directive's applicability to standard terms and conditions of online service providers ("Application of the Unfair Contract Terms Directive to Online Contractual Terms" section). Thereafter, we discuss various types of contractual terms that could be contested by clients of these online service providers as well as by consumer organizations with regard to their compliance with the Directive. ${ }^{9}$ We evaluate contractual terms that allow for unilateral changes of other contractual terms ("Unilateral Changes of Contractual Terms" section) or of the service itself ("Unilateral Changes of the Service Itself" section), terms that allow for unilateral termination of the contract by the online service provider ("Unilateral Termination of the Contract by the Online Service Provider" section), exclusions or limitations of liability ("Liability Exclusions and Limitations" section), international jurisdiction clauses ("International Jurisdiction Clauses" section), and choice-of-law clauses ("Choice-of-law Clauses" section). We finish our analysis by illustrating the overarching problem of many online contractual terms, namely, their lack of transparency ("Transparency" section). In this last section, we indicate how the matter of transparency of standard terms and conditions may interrelate with questions of substantive fairness under EU law and what, therefore, the consequences may be of a breach of the transparency requirement. In our conclusions ("Conclusions" section), we briefly summarize the substantive inadequacies of many online contractual terms, suggesting that enforcement of compliance of such terms with European consumer law should be strengthened in the coming years to add an incentive for online sellers and service providers to comply with the standards for consumer protection set by the European legislator.

\section{Application of the Unfair Contract Terms Directive to Online Contractual Terms}

The Unfair Contract Terms Directive only applies to contractual terms: Article 2 under (a) of the Directive defines "unfair terms" as "the contractual terms defined in Article 3." The Directive does not elaborate on the notion of a "contractual term." This implies that the term must be interpreted autonomously in accordance with the common principles of the Member States' private law systems. In our view, "contractual terms" are terms that confer a right or an obligation to one of the parties or otherwise regulate the required behaviour of a party in her contractual relationship with the other party. From this, it follows that where standard terms and conditions of online service providers explicitly state or just imply that they assign rights and obligations to the parties, they must be classified as contract terms within the Directive's meaning. Such contractual terms may then be tested against the conditions

\footnotetext{
${ }^{9}$ If a consumer organization would want to represent consumers' interests and argue for an injunction against certain unfair contract terms of these online service providers, it would need to be established that at least some of the clients of these providers fall within the scope of the "consumer" notion.
} 
for unfairness as set in Article 3, paragraph 1 of the Directive. It provides that a contractual term which has not been individually negotiated shall be regarded as unfair if, contrary to the requirement of good faith, it causes a significant imbalance in the parties' rights and obligations arising under the contract, to the detriment of the consumer.

The reference to contractual terms implies that the Directive can only apply if a contract has been concluded between an online seller or supplier and a consumer. Whether this is the case is primarily ${ }^{10}$ a matter of national law. If such is the case, and pursuant to its Article 1, paragraph 1, the Directive regulates unfair terms in such contracts. In any case, the Directive unequivocally requires that the seller or supplier of online services "is acting for purposes relating to his trade, business or profession" (Article 2, under (c), UCTD) and that the user of online services is a consumer as identified under Article 2, under (b), UCTD. With regard to this requirement we observe that while professional parties dominate the market for provision of online services, users of such online services may not always qualify as consumers.

The notion of a "consumer" refers in European consumer law mostly to a natural person concluding a contract for a purpose which falls outside of her trade or profession. ${ }^{11}$ Moreover, according to the CJEU's case-law in matters related to private international law, where a natural person acts both for a private and a professional purpose that person can only then qualify as a consumer within the meaning of European consumer law when the purpose related to that person's trade or profession would be as small as to be negligible. ${ }^{12}$ If this notion's narrow scope also applies to substantive European consumer law (Tonner 2014, p. 397; contrary: Reich and Micklitz 2014, pp. 50-56), then many users of online services may not be seen as consumers within the meaning of European consumer law. Users of cloud-based storage services often store their work-related documents online, users of e-mail services send professional e-mails, and users of social networks may have either professional accounts separate from their personal accounts or use one social network account for both purposes (Wauters et al. 2014b, pp. 19-20). In all these circumstances, the national court would need to

\footnotetext{
${ }^{10}$ Though not exclusively, as the effet utile of the Unfair Contract Terms Directive may require the national legislator or court to determine, e.g., that for the purposes of that Directive a contract in fact has been concluded whereas according to national doctrines of contract law this may not (yet) be the case. This may, for instance, be relevant where a legal system requires a counter-performance (however small) to be provided to the online seller or supplier in order for there to be a contract. We do not touch any further on this potential problem, since our focus lies on the evaluation of the European-wide problems with the application and interpretation of the Directive rather than on specific national issues.

${ }^{11}$ See for instance Article 2 under (b) Unfair Contract Terms Directive; Article 2 under (e) Price Indication Directive (Directive 98/6/EC, OJ 1998, L 80/27); Article 2 under (1) Consumer Sales Directive (Directive 1999/44/EC, OJ 1999, L 171/12; Article 2 under (e) E-Commerce Directive (Directive 2000/31/EC, OJ 2000, L 178/1); Article 2 under (d) Distance Marketing of Financial Services Directive (Directive 2002/65/EC, OJ 2002, L 271); Article 2 under (a) Unfair Commercial Practices Directive (Directive 2005/29/EC, OJ 2005, L 149/22); Article 3 under (a) Consumer Credit Directive (Directive 2008/48/EC, OJ 2008, L 133/66); Article 2, paragraph 1, under (f) Timeshare Directive (Directive 2008/122/EC, OJ 2009, L 33/10); Article 2 under (1) Consumer Rights Directive (Directive 2011/83/EU, OJ 2011, L 304/64); Article 4 under (1) Mortgage Credit Directive (Directive 2014/17/EU, OJ 2014, L 60/34). See also Article 2 under (f) of the proposal for a Regulation on a Common European Sales Law (COM(2011) 635 final). The principal exception is Article 2, paragraph 4, of the Package Travel Directive (Directive 90/314/EEC, OJ 1990, L 158/59), which definition may include also natural persons travelling for business purposes. In the proposal for a new Package Travel Directive (COM(2013) 512 final), the notion of "consumer" is replaced by "traveller," see Article 3 under (6) of the proposal.

${ }^{12}$ It may, therefore, also in substantive European consumer law not suffice that the private use is predominant: CJEU 20 January 2005, case C-464/01, ECLI:EU:C:2005:32 (Gruber), point 41.
} 
determine whether a particular user of online services could be considered a "consumer" and as such could then claim protection against unfair contract terms as granted by the Directive. ${ }^{13}$ However, the Consumer Rights Directive, the most recent general measure of European consumer law, introduces in its Recital 17 a broader definition of a consumer as a natural person who would mainly act for non-professional purposes. Whether such mixed purpose contracts could also fall under the scope of consumer protection granted by the Unfair Contract Terms Directive still needs to be confirmed by the CJEU, but it seems likely that this would be the case. ${ }^{14}$

An important question is whether the Directive is applicable to so-called free online services. It should be remarked that such services in fact are typically not offered for free but rather include hidden charges (Hoofnagle and Whittington 2014, pp. 608-612); instead of monetary payment, consumers pay with their personal data, which are collected either explicitly through registration forms, tacitly through sharing personal information on social network sites, or secretly via cookies (Bradshaw et al. 2011, p. 196; Loos et al. 2011, pp. 750, 756-757; Helberger et al. 2013, pp. 162ff; Wauters et al. 2014b, pp. 10-11). Therefore, in our opinion, online service providers of "free" online services should also comply with the provisions of the Directive. ${ }^{15}$

\section{Unilateral Changes of Contractual Terms}

One of the most commonly drafted contractual terms by online service providers is a clause that allows them to modify the contract's terms and conditions. When parties agree to conclude a contract, they give their consent to enter into a contractual relation governed by a certain division of rights and obligations. When one of the parties retains a right to change these agreed terms and conditions, this creates an imbalance between parties. In order for the national courts to consider such an imbalance unfair under Article 3, paragraph 1, of the Directive, this imbalance would need to be significant and to the consumer's detriment. Annex I to the Directive indicates in its paragraph 1 under (j) that a clause

enabling the seller or supplier to alter the terms of the contract unilaterally without a valid reason which is specified in the contract

may be unfair. However, paragraph 2 under (b) adds that paragraph 1 under (j) is

\footnotetext{
${ }^{13}$ It should be noted that member states are free to extend the scope of their consumer protection rules to persons that do not fall within the definition of the relevant European directive, see already CJEU 14 March 1991, case C-361/89, ECLI:EU:C:1991:118 (Di Pinto), points 21 and 22.

${ }^{14}$ See the opinion of AG Cruz Villalón of 23 April 2015, case C-110/14, ECLI:EU:C:2015:271 (Costea), points 37-44. The Court of Justice, in its decision of 3 September 2015, ECLI:EU:C:2015:538 (Costea) did not deal explicitly with this matter but confirmed that the mere fact that a consumer credit was secured by a mortgage on the immovable property that was used by the consumer in the exercise of his professional capacity as a lawyer does not exclude the private capacity of the consumer in concluding the consumer credit contract (see points 2829 of the judgement).

${ }^{15}$ Moreover, in our view, online service providers that in their standard terms and conditions state "we provide you our services for free" commit a misleading and therefore unfair commercial practice as these services in fact are not provided for free, see Article 5, paragraph 6, and No. 20 in the Annex to the Unfair Commercial Practices Directive. See for a similar argument for US law Hoofnagle and Whittington 2014, pp. 609.
} 
without hindrance to terms under which a seller or supplier reserves the right to alter unilaterally the conditions of a contract of indeterminate duration, provided that he is required to inform the consumer with reasonable notice and that the consumer is free to dissolve the contract.

In addition, pursuant to paragraph 1 under (1), a clause

providing for the price of goods to be determined at the time of delivery or allowing a seller of goods or supplier of services to increase their price without in both cases giving the consumer the corresponding right to cancel the contract if the final price is too high in relation to the price agreed when the contract was concluded

may be unfair, whereas paragraph 2 under (d) provides that this provision

is without hindrance to price-indexation clauses, where lawful, provided that the method by which prices vary is explicitly described.

The CJEU interpreted ${ }^{16}$ the above-mentioned provisions in their application to clauses awarding the trader a unilateral right to modify price terms and decided that they may be considered to be fair only if two conditions have been met simultaneously:

(1) The contract itself indicates under which conditions the price may be changed and according to which criteria the change is to be calculated;

(2) Consumers must have the right to terminate the contract after having been informed that the trader indeed wishes to change the price (Keirsbilck 2013, pp. 1471-1472; Leone 2014, pp. 316-319; Micklitz and Reich 2014, pp. 786-789; Terryn 2013, pp. 692-693).

Online traders will not fulfil this first criterion by adding a mere reference to the applicable legislation in their terms and conditions. That is to say, simply stating that changes of the standard terms and conditions are possible "in accordance with applicable national law" is not sufficient. Instead, the conditions for adjusting contractual provisions will need to be spelled out in the contract or in the standard terms and conditions themselves. Moreover, online service providers cannot compensate the breach of this requirement by informing the consumer at a later moment during the contractual performance that the price will be changed. Even if they relay this information in good time before the price's variation occurs, and together with the information on the consumer's right to terminate the contract if she does not wish to accept the variation, this information would be provided too late for the consumer who is already contractually bound. Only by informing the consumer before the contract's conclusion under what conditions the price may be changed and what the calculation method of such changes is can the trader's legitimate interest in being able to respond to a change of circumstances be balanced against the consumer's equally legitimate interests (Rott 2013, pp. 734-735;

\footnotetext{
${ }^{16}$ In particular ECJ 26 April 2012, case C-472/10, ECLI:EU:C:2012:242 (NFH/Invitel); ECJ 21 March 2013, case C-92/11, ECLI:C:EU:2013:180 (RWE Vertrieb AG/Verbraucherzentrale Nordrhein-Westfalen eV); ECJ 30 April 2014, case C-26/13, ECLI:EU:C:2014:282 (Kásler and Káslerné Rábai/OTP Jelzálogbank Zrt).
} 
Terryn 2013, p. 693). First, consumers should be able to foresee the consequences, which such a change might in the future have for them. Second, they should have the necessary data allowing them to react in the best way to their new situation, the CJEU reasoned (Leone 2014, pp. 319-320; Wauters et al. 2014a, p. 8). ${ }^{17}$

Moreover, the traders must offer consumers the right to terminate the contract, which is the second criterion, in addition to fulfilling the first criterion (Micklitz 2014, p. 145; Rott 2013, p. 738). In respect of this requirement, the court stated that

(...) it is of fundamental importance (...) that the right of termination given to the consumer is not purely formal but can actually be exercised. That would not be the case if, for reasons connected with the method of exercise of the right of termination or the conditions of the market concerned, the consumer has no real possibility of changing supplier (...). ${ }^{18}$

In our opinion, in the area of online service providers, consumers could - at least in theory - shop for alternative terms and conditions, suggesting that they can indeed effectively be offered the possibility to terminate the contract.

Although all cases so far decided by the CJEU with regard to modification terms pertain to changes of the price or costs charged to the consumer, there does not seem to be a good reason not to apply the same reasoning to other unilateral changes of the contract, in particular, if they would substantially alter the parties' other rights and obligations (Leone 2014, pp. 322-323). In other words, and even though paragraph 1 under (1) of the Annex to the Directive refers only to the change of contractual terms defining the price as potentially unfair, in our opinion, the national courts could apply this provision analogically to a substantial change of other terms and conditions. We expect they will declare the terms allowing for such changes to be unfair if the conditions under which the terms and conditions may be changed are not valid or not specified in the contract or if consumers are not given an opportunity to terminate the contract. Obviously, the Court of Justice itself could expand its argument in this direction if it were so invited by a national court's request for a prejudicial decision.

If national courts or the Court of Justice itself indeed follow this line of reasoning, than online service providers will find themselves in a lot of trouble. The terms analysed by us and used by Facebook, Twitter, Google, and Dropbox are shown in Table 1. Google ${ }^{19}$ mentions that it may modify the standard terms to "for example, reflect changes to the law or changes to our Services." As we have explained above, such a general disclaimer may not satisfy the condition of paragraph 1 under (j) of the Annex to the Directive to provide valid reasons for change of contractual terms and conditions. Especially, since the online service provider secures himself a right to unilaterally change terms and conditions upon a unilateral change of services. This practice would then remain fully discretionary and thus potentially unfair. Consumers are not notified of changes but are expected to regularly check the website containing

\footnotetext{
${ }^{17}$ CJEU 21 March 2013, case C-92/11, ECLI:C:EU:2013:180 (RWE Vertrieb AG/Verbraucherzentrale Nordrhein-Westfalen eV), points 50-53.

${ }^{18}$ CJEU 21 March 2013, case C-92/11, ECLI:C:EU:2013:180 (RWE Vertrieb AG/Verbraucherzentrale Nordrhein-Westfalen eV), point 54.

${ }^{19}$ Google Terms of Service under the heading "About these Terms."
} 
Table 1 Terms allowing for unilateral changes of contractual terms

Facebook We'll notify you before we make changes to these terms and give you the opportunity to review and comment on the revised terms before continuing to use our Services.

If we make changes to policies, guidelines or other terms referenced in or incorporated by this Statement, we may provide notice on the Site Governance Page.

Your continued use of Facebook following notice of the changes to our terms, policies, or guidelines, constitutes your acceptance of our amended terms, policies or guidelines.

Twitter We may revise these Terms from time to time, the most current version will always be at twitter.com/tos. If the revision, in our sole discretion, is material we will notify you via an @ Twitter update or e-mail to the email associated with your account. By continuing to access or use the Services after those revisions become effective, you agree to be bound by the revised Terms.

Google We may modify these terms or any additional terms that apply to a Service to, for example, reflect changes to the law or changes to our Services. You should look at the terms regularly. We'll post notice of modifications to these terms on this page. We'll post notice of modified additional terms in the applicable Service. Changes will not apply retroactively and will become effective no sooner than 14 days after they are posted. However, changes addressing new functions for a Service or changes made for legal reasons will be effective immediately. If you do not agree to the modified terms for a Service, you should discontinue your use of that Service.

Dropbox We may revise these Terms from time to time, and will always post the most current version on our website. If a revision meaningfully reduces your rights, we will notify you (by, for example, sending a message to the email address associated with your account, posting on our blog or on this page). By continuing to use or access the Services after the revisions come into effect, you agree to be bound by the revised Terms.

the standard terms, on which website the changes to the terms will be published (Bradshaw et al. 2011, pp. 191-192, 202; 216-217). As a result, consumers may not even be aware that the standard terms and conditions of their contracts have changed. Google respects a notice period of 2 weeks, except for such amendments of standard terms that reflect changes to the law and changes addressing new functions for a service. A consumer who does not accept the changes only has the choice to discontinue the use of the respective service, i.e., to terminate the contract. Both the use of the words "for example" in determining for what reason the unilateral change may occur and the exception to the availability of a notice period for amendments reflecting changes to the law or changes resulting from the introduction of new functions to Google's services indicate that the enumeration of situations under which the terms may be changed is not exhaustive. This clearly does not meet the first fairness requirement as set out above. The second requirement that may be deduced from the case-law of the CJEU and may analogically be applied to all terms and conditions is only partially fulfilled, since while consumers in theory have a right to terminate the contract after having been informed about the changes, the lack of notification of these changes reduces the effectiveness of the right to terminate the contract.

The standard terms of the other online service providers under scrutiny are at least as vague as to the reasons that could lead to a unilateral change of terms and conditions. Moreover, they do not even mention the option for the consumer to terminate the contract if she does not want to accept changed terms, albeit that termination is available for any reason according to their policies. Arguably, Google provides therefore the best practice with regard to this contract term. 
Facebook $^{20}$ indicates it will notify consumers before it changes its Statement of Rights and Responsibilities but does not indicate how long before the change it will do so. ${ }^{21}$ Moreover, the text of the Statement of Rights and Responsibilities does not indicate how Facebook will notify the changes. It does not even attempt to avoid the charge of potential unfairness on the basis of paragraph 1 under ( $\mathrm{j}$ ) of the Annex to the Directive since there is no explanation given as to what could lead to such a unilateral change of its terms and conditions. Still, it is clear that changes to (for instance privacy) policies, guidelines, or other terms may occur and then they apparently will only be posted on the Facebook's Site Governance Page, if it all. ${ }^{22}$ Facebook users may thus also miss the fact that their contracts have changed. Continued use of the service amounts to acceptance of the changes (Rustad and Onufrio 2012, p. 1114). Facebook does not inform consumers about the possibility to terminate the contract, although one could argue that if a consumer no longer uses the service this may be interpreted as termination. According to the standard terms, the consumer may terminate the contract for whatever reasons by deleting her account. However, the standard terms also provide that most of the terms continue to apply even after termination. This clearly does not meet any of the two conditions set out by the CJEU.

Dropbox $^{23}$ as well provides no reason at all for changes to its standard terms. Notification will occur only if a revision meaningfully reduces consumer's rights, but whether a change is minor or major apparently is left to the discretion of Dropbox. Moreover, consumers may be notified through an e-mail sent to the e-mail address provided by the consumer when contracting with Dropbox or through a post on a blog operated by Dropbox or on the website where the terms are published. Obviously, most consumers are unlikely to notice the latter type of notification. Continued use of the service, again, amounts to acceptance of the changes. Consumers may terminate the contract but are not specifically informed of that possibility. ${ }^{24}$

Finally, under the misleading heading entire agreement, Twitter ${ }^{25}$ reserves the right to change the terms at any time for any reason. This broad term also does not list valid reasons that could justify the adjustment of contractual terms and conditions, which makes it potentially unfair pursuant to paragraph 1 under (j) of the Annex to the Directive. Only material changes, to be determined in the sole discretion of Twitter, will be notified. Notification will then occur either by an update message or by an e-mail to the e-mail address provided by the consumer when the account was created, suggesting that such notification should indeed reach the consumer. Continued use of the service, once more, amounts to acceptance of the changes. And anew, consumers may terminate the contract but are not specifically informed of that possibility, and the most relevant terms continue to apply even after termination. ${ }^{26}$

In sum, the terms and conditions of the online service providers analysed by us clearly fall under the category of terms that potentially are unfair, in particular if national courts would analogically apply paragraph 1 under (j) of the Annex to the Directive. Moreover, and assuming that national courts or the CJEU itself will indeed extend the current case-law on clauses allowing for a unilateral change of the price to clauses allowing for changes of other

\footnotetext{
${ }^{20}$ Article 13.1 of the Statement of Rights and Responsibilities.

${ }^{21}$ In an earlier version of the Statement of Rights and Responsibilities, Facebook indicated to respect a notice period of 7 days.

${ }^{22}$ See 13.2 of the Statement of Rights and Responsibilities.

${ }^{23}$ Dropbox Terms of Service under the heading "Modifications."

${ }^{24}$ Dropbox Terms of Service under the heading "Termination."

25 Article 12 under C of the Terms of Service.

${ }^{26}$ Article 10 of the Terms of Service.
} 
contractual terms, all standard contract terms of online service providers investigated by us fail to meet the conditions set by the CJEU on the basis of paragraph 1 under (l) of the Annex to the Directive. Online service providers seem to expect consumers to regularly check online whether standard contract terms have been adjusted and do not inform them clearly about their right to terminate the contract. Considering the rapidly evolving technologies, which may require continuous revision of existing terms of contract, there is a clear need for a better oversight over existing practices in this field (Wauters et al. 2014a, p. 8). ${ }^{27}$

\section{Unilateral Changes of the Service Itself}

The above-discussed unilateral right to modify contract terms differs from a right to modify services, but the second can be the result of the first, since adjustment of the contract terms may concern variation in the services' definition or scope. When consumers conclude a contract with an online service provider, they expect to receive a certain service. If the service provider could unilaterally decide to change this service's scope or nature that could leave a consumer bound to a contract she might not have wanted.

Paragraph 1 under $(\mathrm{k})$ of Annex I to the Directive lists a clause

enabling the seller or supplier to alter unilaterally without a valid reason any characteristics of the product or service to be provided

as potentially unfair. Just like with clauses that allow online service providers to modify contract terms, service providers should, therefore, be able to justify the need to modify their services and should not grant themselves an unlimited unilateral right to modify services. Nevertheless, due to the fact that paragraph 2 under (b) of the Annex to the Directive does not apply to services' changes, the Directive does not explicitly require the service providers to inform consumers of their intention to modify the services or to give them a reasonable amount of time to respond to such a plan, including a right to terminate the contract. National laws may have, however, introduced such obligations to safeguard the balance between the parties' rights and obligations. Moreover, it is feasible that the CJEU, in line with its reasoning with regard to terms allowing for the unilateral change of contract terms, ${ }^{28}$ will argue that a term allowing for a change of the services to be rendered can only be considered transparent if it enables the consumer to foresee, on the basis of clear, intelligible criteria, which economic consequences derive for her from the term. If the CJEU would follow this path, such terms would be allowed only if a consumer would be able to foresee under which conditions and circumstances the trader might want to invoke the term.

We, therefore, argue that a change of the service should be subject to the same requirements as changes to the contract terms and the price, i.e.,

(1) The contract indicates under which conditions the service may be changed and according to which criteria the change is to be calculated;

(2) Consumers have the right to terminate the contract after having been informed that the trader indeed wishes to change the service.

\footnotetext{
${ }^{27}$ For example, Google's privacy policy has been modified 12 times since 2001, see https://www.google.com/ intl/en/policies/privacy/archive/ (last visited on 2 December 2014).

${ }^{28}$ See the section "Unilateral Changes of Contractual Terms."
} 
Table 2 Terms allowing for a unilateral change of the service

Facebook We'll notify you before we make changes to these terms and give you the opportunity to review and comment on the revised terms before continuing to use our Services.

If we make changes to policies, guidelines or other terms referenced in or incorporated by this Statement, we may provide notice on the Site Governance Page.

Your continued use of Facebook following notice of the changes to our terms, policies or guidelines, constitutes your acceptance of our amended terms, policies or guidelines.

Twitter The Services that Twitter provides are always evolving and the form and nature of the Services that Twitter provides may change from time to time without prior notice to you. In addition, Twitter may stop (permanently or temporarily) providing the Services (or any features within the Services) to you or to users generally and may not be able to provide you with prior notice. We also retain the right to create limits on use and storage at our sole discretion at any time without prior notice to you.

(...)

Nothing in this section shall affect Twitter's rights to change, limit or stop the provision of the Services without prior notice, as provided above in the "Introduction."

Google We are constantly changing and improving our Services. We may add or remove functionalities or features, and we may suspend or stop a Service altogether.

You can stop using our Services at any time, although we'll be sorry to see you go. Google may also stop providing Services to you, or add or create new limits to our Services at any time.

We believe that you own your data and preserving your access to such data is important. If we discontinue a Service, where reasonably possible, we will give you reasonable advance notice and a chance to get information out of that Service.

Dropbox

However, as online services may need to be altered both frequently and unexpectedly, the requirement that the contract also sets out the criteria according to which the change is to be determined might not be entirely suitable to be taken over. For that reason, we will leave that part of the conditions set by the CJEU out of consideration when assessing the standard terms of the online service providers (Table 2).

The standard terms used by Facebook ${ }^{29}$ do not stipulate specific rules pertaining to changes of the service. Given the fact that the provision already mentioned in Table 1 does not restrict its application's scope to changes to the Facebook's standard terms, this provision must be intended to apply also with regard to changes of the service itself. We may, therefore, refer to the objections raised in the previous section. This means that Facebook's standard contract terms and conditions are potentially unfair since they fall under the category of terms that paragraph 1 under $(\mathrm{k})$ of the Annex to the Directive describes and do not follow the abovementioned conditions set by the CJEU that we consider should be used in the unfairness' assessment of these terms.

The standard terms of Twitter $^{30}$ provide that Twitter may occasionally change the services' form and nature without prior notice to the consumer or even permanently or temporarily stop providing the services or any features within them, again without giving prior notice. According to its terms, Twitter, therefore, neither needs to give notice, nor state reasons for the service's change, nor does it have to inform consumers of their right to terminate the contract. Twitter's standard terms and conditions are, therefore, as likely to be assessed as unfair as Facebook's.

${ }^{29}$ Article 14 of the Statement of Rights and Responsibilities.

${ }^{30}$ Article 1 and Article 10 in fine of the Terms of Service. 
The terms used by Dropbox do not seem to allow for a service's change. However, Dropbox reserves the right to suspend or end the contract at any time at its discretion and without giving notice. ${ }^{31}$ This effectively means that if Dropbox wishes to change its service, it could simply terminate the contract with all of its customers and offer to conclude new contracts for a changed service. Whether such a term is valid will be discussed in the following section.

Finally, Google's terms ${ }^{32}$ explicitly allow for a modification of the offered services by adding or removing functionalities or features, adding or creating limitations to the services, or terminating the services altogether at any time. Only in the case of termination of a specific service the consumer is given a reasonable advance notice and a chance to remove her data out of the service concerned (as Google describes it).

Clearly, these terms that provide for a unilateral right for the online service provider to change the service itself do not meet the requirements set out in this section. We believe that the standard terms used by Facebook, Twitter, and Google on this point are unfair. Even if one would argue that due to the ever-changing circumstances in the online environment one could not expect that the standard terms would have to list under which conditions the service may be changed, this argument would not seem to hold with regard to the requirement of a reasonable notice and pointing the consumer to the possibility to terminate the contract. However, the standard contract terms used by these online service providers do not even meet these less burdensome conditions.

\section{Unilateral Termination of the Contract by the Online Service Provider}

Another clause that can significantly distort the balance between a consumer and a service provider is a clause that gives the latter a unilateral right to terminate the contract at any time, for whatever reason. When consumers conclude contracts to use online services they expect, amongst other things, to be able to store their documents and photos (in case of cloud-based storage services or social networks) or to communicate with their families and friends (in case of social networks or e-mailing services). Clearly, from the consumer's perspective, if the online service provider could terminate the contract at any time and for any reason that could seriously undermine the whole purpose of entering into the contract. Hence, if an online service provider informs consumers in advance that, e.g., they would only be able to store documents online, send e-mails, or use a social network for a month or two, such consumers would be likely to choose the service of another, more reliable party instead.

In many cases, the service offered by online service providers is "free of charge," that is, not paid for in money. Whether consumers pay for online services in money or not may influence the evaluation of the unfair character of a contractual term. First, consumers may expect less certainty from a "free" service. Second, consumers could then not as easily prove that due to the service provider's right to unilaterally terminate the contract without a valid reason the parties' position would be significantly unbalanced. However, in many cases, consumers pay for such "free" services in other than monetary ways, typically, by being

\footnotetext{
31 See the Terms of Service of Dropbox under the heading "Termination."

${ }^{32}$ Google Terms of Service under the heading "Modifying and Terminating our Services."
} 
exposed to advertisements or by providing their personal data (see above the "Application of the Unfair Contract Terms Directive to Online Contractual Terms" section). The fact that the consumer does not pay a price in money can, therefore, not justify the online service provider's right to terminate a contract for whatever reason at any time, in particular not, when the consumer has already provided her personal data and thus has rendered her performance. This fact should, therefore, be taken into account in the evaluation.

Changed circumstances may force a trader to discontinue a product or a service offered by that trader. For that reason, a term allowing the trader to unilaterally terminate the contract may be fair under certain conditions. However, such a term should consider the reasonable interests of the consumer. A right to unilaterally terminate the contract may be unfair, in particular, where the consumer has a reasonable interest in preserving the contract's longevity, because she has foreseeably invested time and effort in the services offered by the trader, e.g., by importing and storing data in "her" part of the cloud. This is all the more true if the trader does not inform the consumer of its intention to terminate the contract or the service or does not observe a reasonably long notice period allowing the consumer to withdraw her data from the cloud and transferring it elsewhere (Bradshaw et al. 2011, pp. 203204).

The Annex to the Directive contains two provisions dealing with the contract's termination by the trader: paragraph 1 under (f) lists as a potentially unfair contract term a clause

authorizing the seller or supplier to dissolve the contract on a discretionary basis where the same facility is not granted to the consumer, or permitting the seller or supplier to retain the sums paid for services not yet supplied by him where it is the seller or supplier himself who dissolves the contract.

In addition, paragraph 1 under $(\mathrm{g})$ concerns terms

enabling the seller or supplier to terminate a contract of indeterminate duration without reasonable notice except where there are serious grounds for doing so.

The provision under (f) deals with reciprocity: If the trader reserves his right to terminate unilaterally at will, such a clause is likely to be fair only where the consumer may do the same. It should be noted that the mere fact that the consumer is awarded a similar right to unilaterally terminate the contract does not automatically signify that the term is fair. As paragraph 1 under (f) of the Annex to the Directive indicates, the term could still be unfair if it allows the trader when he terminates the contract to keep the consumer's remuneration for services not yet rendered. Such a term would imply that the trader receives at least a part of his remuneration for services he does not render. This could apply also in cases of "free" services where the trader is able to continue using (or selling) personal data received from the consumer without performing his part of the contract. The provision under $(\mathrm{g})$ clarifies that in the case of a contract of indeterminate duration, i.e., a contract that does not end automatically and can only end through termination, termination by the trader in itself may be justified but the trader either is required to have serious reasons for termination with immediate effect or needs to respect a reasonable notice period. Therefore, terms allowing the trader to terminate the contract with immediate effect without there being serious reasons for such termination may be considered unfair. In such circumstances, additional problems may arise if the trader has immediately upon termination of the service deleted the consumer's data stored within the service (Bradshaw et al. 2011, p. 204). 
It seems likely that the CJEU, as it did with regard to terms allowing for a unilateral change of the price, will jointly evaluate these two Directive's provisions when determining under which conditions a term allowing for unilateral termination can be considered as fair. In this respect, it should be remarked that if unilateral termination is possible too easily, contractual performance would be entirely dependent on the trader's discretion, which would undermine the consumer's trust in the binding force of the contract. Moreover, if unilateral termination is readily available to the trader, this would undermine the effectiveness of the rules developed by the CJEU to restrict the validity of terms allowing for a unilateral change of the price, as such rules could then be easily circumvented by traders simply terminating the contract and offering the consumer to conclude a new contract under acceptance of the changed standard terms or price.

Therefore, we predict that the CJEU would interpret paragraphs 1 under (f) and (g) of the Annex to the Directive in a way that would find a standard term allowing for unilateral termination by the trader to be unfair if

(1) The trader need not notify the termination before effecting it (on the basis of paragraph 1 under ( $\mathrm{g}$ ) of the Annex to the Directive);

(2) The trader need not state any reasons for termination (on the basis of paragraph 1 under (g) of the Annex to the Directive);

(3) The trader may terminate the contract also in case of minor infringement of the contract terms by the consumer (on the basis of paragraph 1 under (g) of the Annex to the Directive);

(4) The reasons for termination have not been stated in the contract or in the standard terms (on the basis of paragraph 1 under ( $g$ ) of the Annex to the Directive);

(5) The trader is not required to observe a reasonable period for termination, taking into account the consumer's reasonable interests, apart from serious reasons justifying immediate termination (on the basis of paragraph 1 under (g) of the Annex to the Directive);

(6) It is left up to the trader's sole discretion to determine whether there is a serious reason justifying immediate termination (on the basis of paragraph 1 under (g) of the Annex to the Directive);

(7) The consumer is not awarded a similar right of unilateral termination at will (on the basis of paragraph 1 under (f) of the Annex to the Directive); or

(8) The trader is allowed to keep prepayments made by the consumer for services not rendered (on the basis of paragraph 1 under (f) of the Annex to the Directive).

On the other hand, if the trader has drafted the termination clause in such a way that the right to termination is limited to situations where the trader has a valid reason for it, these reasons have been stated in the contract, and a reasonable notice period would be observed, it is likely that a national court would not find such a term unfair, in particular if a reciprocal right would be granted to the consumer. A valid reason could be found in a situation where the consumer violated the terms of the service and the infringement was not merely minor in nature, but also where a digital product was outdated and replaced by a new product, making it economically unviable to continue the service. Moreover, the trader could almost certainly avoid the abusive character of the clause if he gave consumer an option to contest his reason for termination and if the termination would not be effected until a court or an ADR or ODR institution had ruled on the consumer's complaint.

The relevant terms used by Facebook, Twitter, Google, and Dropbox with respect to unilateral termination are shown in Table 3. 
Table 3 Terms allowing for unilateral termination by a service provider

Facebook If you violate the letter or spirit of this Statement, or otherwise create risk or possible legal exposure for us, we can stop providing all or part of Facebook to you. We will notify you by email or at the next time you attempt to access your account. You may also delete your account or disable your application at any time. In all such cases, this Statement shall terminate, but the following provisions will still apply: 2.2, 2.4, 3-5, 89.3, and 14-18.

Twitter You may end your legal agreement with Twitter at any time for any or no reason by deactivating your accounts and discontinuing your use of the Services. You do not need to specifically inform Twitter when you stop using the Services. If you stop using the Services without deactivating your accounts, your accounts may be deactivated due to prolonged inactivity under our Inactive Account Policy.

We may suspend or terminate your accounts or cease providing you with all or part of the Services at any time for any reason, including, but not limited to, if we reasonably believe: (i) you have violated these Terms or the Twitter Rules, (ii) you create risk or possible legal exposure for us; or (iii) our provision of the Services to you is no longer commercially viable. We will make reasonable efforts to notify you by the email address associated with your account or the next time you attempt to access your account.

In all such cases, the Terms shall terminate, including, without limitation, your license to use the Services, except that the following sections shall continue to apply: 4, 5, 7, 8, 10, 11, and 12 .

Nothing in this section shall affect Twitter's rights to change, limit or stop the provision of the Services without prior notice, as provided above in the section "Introduction."

Google We are constantly changing and improving our Services. We may add or remove functionalities or features, and we may suspend or stop a Service altogether.

You can stop using our Services at any time, although we'll be sorry to see you go. Google may also stop providing Services to you, or add or create new limits to our Services at any time.

We believe that you own your data and preserving your access to such data is important. If we discontinue a Service, where reasonably possible, we will give you reasonable advance notice and a chance to get information out of that Service.

Dropbox You're free to stop using our Services at any time. We also reserve the right to suspend or end the Services at any time at our discretion and without notice. For example, we may suspend or terminate your use of the Services if you're not complying with these Terms, or use the Services in a manner that would cause us legal liability, disrupt the Services or disrupt others' use of the Services. Except for Paid Accounts, we reserve the right to terminate and delete your account if you haven't accessed our Services for 12 consecutive months. We'll of course provide you with notice via the email address associated with your account before we do so.

First, we remark that consumer contracts with these online service providers are usually of indeterminate duration, which means that paragraph 1 under $(\mathrm{g})$ of the Annex to the Directive applies to them. Dropbox's terms ${ }^{33}$ reserve the right for Dropbox to suspend or end services at any time at its discretion and without notice. This provision, therefore, mirrors the presumably unfair terms listed above under (1) and (2). In our view, the term is hence to be considered unfair on these two grounds. Exceptionally, when Dropbox terminates the contract due to non-activity during 12 consecutive months, Dropbox commits itself to give the consumer prior notice via the e-mail address associated with the consumer's account. However, Dropbox still does not indicate how far in advance such a notice must be given (Bradshaw et al. 2011, p. 197). Even if we acknowledge that this term meets the first two requirements, it could, nevertheless, be regarded as unfair if the court would find the absence of an indication as to the length of the notice period as not prescribing a reasonable period

${ }^{33}$ See the Terms of Service of Dropbox under the heading "Termination." 
for termination, as listed above under (5). These provisions are then potentially unfair on the basis of paragraph 1 under $(\mathrm{g})$ of the Annex to the Directive. However, since Dropbox provides for a reciprocal right of unilateral termination to its consumers, consumers could not invoke paragraph 1 under (f) of the Annex to the Directive against Dropbrox.

Facebook ${ }^{34}$ provides that when the consumer violates the contract's letter or spirit, or if she otherwise creates risk or possible legal exposure for Facebook, it may terminate the contract. In particular, the latter part of this clause is drafted so broadly that even writing this paper could instigate a contract's termination by Facebook of any Facebook-account we might have (Leydon 2013; Moses 2008). Moreover, the same term states that notification may be provided by e-mail or on the Facebook website the next time when the consumer attempts to access her account, suggesting that termination has already taken effect without respecting any notice period. Clearly, several of the possibly unfair terms listed above, in particular the ones listed under (1), (3), and (5), could be invoked here to contest the validity of Facebook's terms (Rustad and Onufrio 2012, p. 1114; Wauters et al. 2014b, pp. 31-34). Again, consumers could contest Facebook's terms on the basis that they fall under the category of potentially unfair contract terms as described in paragraph 1 under (g) of the Annex to the Directive, but not be able to invoke paragraph 1 under (f) of the Annex to the Directive.

The same applies to the standard terms used by Twitter. $^{35}$ In addition, Twitter provides in its terms that it may suspend or terminate the contract if it "reasonably believe $[s]$ " that the consumer has violated the contract terms or the Twitter Rules. This implies that Twitter need not even prove that the consumer has breached her contractual obligations; it suffices if it reasonably believes that this is the case. This effectively means that the consumer would have to prove that she has not breached the contract, thus reversing the burden of proof. Such a term is listed as potentially unfair in the Annex to the Directive under paragraph 1 sub (q). And even if the consumer would prove that she has not violated the contract, this still may not be enough if Twitter nevertheless believes otherwise. In other words, this term in fact resembles also the possibly unfair terms listed under (2) and (6), reflecting some of the requirements listed in paragraph 1 under $(\mathrm{g})$ of the Annex to the Directive.

Finally, Google's terms ${ }^{36}$ provide that it may suspend or stop a service altogether and, more specifically, that it may stop providing services to a particular consumer. This creates an unlimited, unrestricted termination right. Moreover, Google does not need to observe the notice requirement and termination of the contract may take immediate effect. Clearly, this term mirrors listed clauses (1) to (6) and is likely to be considered unfair on the basis of paragraph 1 under $(\mathrm{g})$ of the Annex to the Directive.

We may, therefore, conclude that the termination clauses in the standard contract terms of each of these online service providers appear to be unfair in as far as they do not respect fairness requirements posed for termination of contracts of indeterminate duration. All these online service providers fulfil, however, the requirement of

\footnotetext{
${ }^{34}$ Article 14 of the Statement of Rights and Responsibilities.

35 Article 10 of the Terms of Service.

${ }^{36}$ Google Terms of Service under the heading "Modifying and Terminating our Services."
} 
reciprocity in giving consumers an opportunity to unilaterally terminate their contracts as well.

\section{Liability Exclusions and Limitations}

Online service providers may have valid reasons for limiting their liability against consumers. Even if this does not apply to the cases we have analysed, online service providers often are small businesses that could not afford being sued to cover potentially extensive losses sustained by consumers, especially when they deliver their services to consumers without receiving payment in money. Therefore, under certain circumstances, clauses limiting or excluding the liability of online service providers could be justified. Still, a full exclusion or a broad limitation of liability, regardless of what caused the damage, whether the damage was caused intentionally or through gross negligent behaviour, and regardless of the type of damage sustained, will often be seen as unjustified, significantly distorting the balance between the parties' rights and obligations and, therefore, unfair (Bradshaw et al. 2011, p. 211; Wauters et al. 2014b, p. 26).

Annex I, paragraph 1 under (a) to the Directive mentions as potentially unfair a clause

excluding or limiting the legal liability of a seller or supplier in the event of the death of a consumer or personal injury to the latter resulting from an act or omission of that seller or supplier

and paragraph 1 under (b) a clause

inappropriately excluding or limiting the legal rights of the consumer vis-á-vis the seller or supplier or another party in the event of total or partial non-performance or inadequate performance by the seller or supplier of any of the contractual obligations (...).

While it may be difficult to imagine a situation where an act of an online service provider leads to the consumer's death or a personal injury, ${ }^{37}$ it is feasible to foresee an online service provider's failure to properly perform its services. The question is then whether and under which circumstances the exclusion or limitation of liability may be "inappropriate."

The terms used by Facebook, ${ }^{38}$ Twitter, ${ }^{39}$ Google, ${ }^{40}$ and Dropbox ${ }^{41}$ to exclude or limit their liability towards their clients are shown in Table 4. All examined online service providers include a clause in their standard terms and conditions that states that services are provided as is (Bradshaw et al. 2011, p. 215; Rustad and Onufrio 2012, p. 1126). The purpose of this clause is to exclude the online service provider's liability for any disturbance in the availability or reliability of the service and to ascertain that he gives no guarantees with regard to the provision of his services. Indirectly, the clause, therefore, aims to exclude any liability by stating that the consumer could not reasonably expect the service to be rendered without disturbances. It may depend on a given national law whether such a clause would be considered or presumed unfair. It seems clear, however, that there will be circumstances, in

\footnotetext{
${ }^{37}$ Though it is imaginable that some people may be significantly emotionally disturbed if their online services are blocked or disrupted, in particular if, e.g., their digital photographs are erased.

${ }^{38}$ Article 15.3 of the Statement of Rights and Responsibilities of Facebook.

${ }^{39}$ Article 11 under A of the Terms of Service.

${ }^{40}$ See Google Terms of Service under the heading "Our Warranties and Disclaimers."

${ }^{41}$ Terms of Service of Dropbox under the heading "Services 'AS IS."
} 
Table 4 Terms limiting or excluding liability by indicating that service is provided 'as is'

Facebook We try to keep Facebook up, bug-free, and safe, but you use it at your own risk. We are providing Facebook as is without any express or implied warranties including, but not limited to, implied warranties of merchantability, fitness for a particular purpose, and non-infringement. We do not guarantee that Facebook will always be safe, secure or error-free or that Facebook will always function without disruptions, delays or imperfections. Facebook is not responsible for the actions, content, information, or data of third parties, and you release us, our directors, officers, employees, and agents from any claims and damages, known and unknown, arising out of or in any way connected with any claim you have against any such third parties.

Twitter Your access to and use of the services or any content are at your own risk. You understand and agree that the Services are provided to you on an "AS IS" and "as available" basis. Without limiting the foregoing, to the maximum extent permitted under applicable law, the twitter entities disclaim all warranties and conditions, whether express or implied, of merchantability, fitness for a particular purpose, or non-infringement.

The Twitter Entities make no warranty or representation and disclaim all responsibility and liability for: (i) the completeness, accuracy, availability, timeliness, security or reliability of the Services or any Content; (ii) any harm to your computer system, loss of data, or other harm that results from your access to or use of the Services or any Content; (iii) the deletion of, or the failure to store or to transmit, any Content and other communications maintained by the Services; and (iv) whether the Services will meet your requirements or be available on an uninterrupted, secure, or error-free basis. No advice or information, whether oral or written, obtained from the Twitter Entities or through the Services, will create any warranty or representation not expressly made herein.

Google We provide our Services using a commercially reasonable level of skill and care and we hope that you will enjoy using them. But there are certain things that we don't promise about our Services.

Other than as expressly set out in these terms or additional terms, neither Google nor its suppliers or distributors make any specific promises about the Services. For example, we don't make any commitments about the content within the Services, the specific functions of the Services, or their reliability, availability, or ability to meet your needs. We provide the Services "as is."

Some jurisdictions provide for certain warranties, like the implied warranty of merchantability, fitness for a particular purpose and non-infringement. To the extent permitted by law, we exclude all warranties.

Dropbox We strive to provide great services, but there are certain things that we can't guarantee. To the fullest extent permitted by law, Dropbox and its affiliates, suppliers and distributors make no warranties, either express or implied, about the services. The services are provided "as is." We also disclaim any warranties of merchantability, fitness for a particular purpose and non-infringement. Some places don't allow the disclaimers in this paragraph, so they may not apply to you.

which the service may not be available to the consumer due to the service provider's fault or negligence. In our view, this term unfairly does not distinguish between disturbances caused due to the service provider's fault or negligence and disturbances caused outside the service provider's sphere. In this respect, we hold this term to be unfair since it seems to "inappropriately" limit the online service provider's liability in the event of nonperformance of his contractual obligations.

In addition, some online service providers further limit their liability by excluding, for instance, data or financial losses, or indirect, special, consequential, exemplary, or punitive damages, or by capping their liability. The relevant terms used by Facebook, ${ }^{42}$ Twitter, ${ }^{43}$ Google, ${ }^{44}$ and Dropbox ${ }^{45}$ are shown in this respect in Table 5.

\footnotetext{
${ }^{42}$ Article 15.3 of the Statement of Rights and Responsibilities of Facebook.

${ }^{43}$ Article 11 under $\mathrm{C}$ of the Terms of Service.

${ }^{44}$ See Google Terms of Service under the heading "Liability for our Services."

45 Terms of Service of Dropbox under the heading "Limitation of Liability."
} 
Table 5 Terms further limiting liability

Facebook Our aggregate liability arising out of this statement or Facebook will not exceed the greater of one hundred dollars $(\$ 100)$ or the amount you have paid us in the past 12 months. applicable law may not allow the limitation or exclusion of liability or incidental or consequential damages, so the above limitation or exclusion may not apply to you. in such cases, Facebook's liability will be limited to the fullest extent permitted by applicable law.

Twitter To the maximum extent permitted by applicable law, the twitter entities shall not be liable for any indirect, incidental, special, consequential or punitive damages, or any loss of profits or revenues, whether incurred directly or indirectly, or any loss of data, use, good-will, or other intangible losses, resulting from (i) your access to or use of or inability to access or use the services; (ii) any conduct or content of any third party on the services, including without limitation, any defamatory, offensive or illegal conduct of other users or third parties; (iii) any content obtained from the services; or (iv) unauthorized access, use or alteration of your transmissions or content.

In no event shall the aggregate liability of the twitter entities exceed the greater of one hundred u.s. dollars (u.s. \$100.00) or the amount you paid twitter, if any, in the past six months for the services giving rise to the claim.

The limitations of this subsection shall apply to any theory of liability, whether based on warranty, contract, statute, tort (including negligence) or otherwise, and whether or not the twitter entities have been informed of the possibility of any such damage, and even if a remedy set forth herein is found to have failed of its essential purpose.

Google When permitted by law, Google, and Google's suppliers and distributors, will not be responsible for lost profits, revenues, or data, financial losses or indirect, special, consequential, exemplary, or punitive damages.

To the extent permitted by law, the total liability of Google, and its suppliers and distributors, for any claims under these terms, including for any implied warranties, is limited to the amount you paid us to use the Services (or, if we choose, to supplying you the Services again).

In all cases, Google, and its suppliers and distributors, will not be liable for any loss or damage that is not reasonably foreseeable.

We recognize that in some countries, you might have legal rights as a consumer. If you are using the Services for a personal purpose, then nothing in these terms or any additional terms limits any consumer legal rights which may not be waived by contract.

Dropbox To the fullest extent permitted by law, except for any liability for Dropbox's or its affiliates' fraud, fraudulent misrepresentation, or gross negligence, in no event will Dropbox, its affiliates, suppliers or distributors be liable for (a) any indirect, special, incidental, punitive, exemplary or consequential damages or (b) any loss of use, data, business, or profits, regardless of legal theory. This will be regardless of whether or not Dropbox or any of its affilliates has been warned of the possibility of such damages, and even if a remedy fails of its essential purpose. Additionally, Dropbox, its affiliates, suppliers and distributors will not be liable for aggregate liability for all claims relating to the services more than the greater of $\$ 20$ or the amounts paid by you to Dropbox for the past 12 months of the services in question. Some places don't allow the types of limitations in this paragraph, so they may not apply to you.

Such additional limitations may also be found unfair, in particular when read in conjunction with the already far-reaching limitation on the basis of the as is term described above. However, the laws of the different Member States may assess such limitations to the online service provider's liability very differently as to what could be seen as an "inappropriate" limitation of their rights in case of the non-performance (Bradshaw et al. 2011, pp. 210-213). Unfortunately, there is no general indication of the acceptability of such terms under EU law. Therefore, it will be necessary to carefully consider the unfairness of exemption clauses or of clauses limiting particular liability under each given national law. 


\section{International Jurisdiction Clauses}

Articles $17-19$ of the Brussels I-Regulation (recast) ${ }^{46}$ create specific jurisdiction for consumer contracts. Article 17, paragraph 1, determines that (in so far as it is relevant here) a contract falls within the scope of these provisions if it is concluded

(1) By a person (the consumer) acting for a purpose outside her trade or profession,

(2) With another party (the trader) who

(a) Pursues commercial or professional activities in the Member State of the consumer's domicile or, by any means, directs such activities to that Member State or to several States including that Member State and

(b) The contract falls within the scope of such activities.

With regard to these requirements, in a joint declaration by the Council and the Commission on Article 15 of the identical provision of the former Brussels I-Regulation $^{47}$, it is stated, inter alia, that for the specific rules of the Brussels I-Regulation pertaining to consumer contracts to apply, the contract concluded must fall within the framework of the targeted activities and that the mere fact that an Internet site is accessible from the consumer's place of residence is not sufficient for their applicability (Cordera 2001, pp. 249-250; Trstenjak 2013, pp. 473-475). This joint declaration identifies as relevant factors in determining whether the requirements of (then) Article 15 of the Brussels I-Regulation are met the fact that the Internet site solicits the conclusion of contracts by consumers at a distance and that the contract is in fact concluded at a distance. The language or currency which a website uses does not constitute such a relevant factor (Wauters et al. 2014b, pp. 20-21). In recent judgments, the CJEU further lowered the requirements for the application of (then) Article 15 Brussels I-Regulation by declaring that even if the contract was not concluded at a distance that should not preclude consumers from enjoying this protection. ${ }^{48}$

If Article 17 Brussels I-Regulation (recast) applies, a claim against the consumer may only be brought in the courts of the Member State in which the consumer is domiciled (Article 18, paragraph 2), whereas the consumer who brings proceedings against the trader may also choose for the courts of the Member State in which the trader is domiciled (Article 18, paragraph 1). The parties may derogate from the provisions of Article 18 to the detriment of the consumer only once a dispute has arisen. ${ }^{49}$ This implies that a contractual derogation of the international jurisdiction rules of the Brussels I-Regulation is contrary to the law. Therefore, it is not even

\footnotetext{
${ }^{46}$ Regulation (EU) no 1215/2012 of the European Parliament and of the Council of 12 December 2012 on jurisdiction and the recognition and enforcement of judgments in civil and commercial matters (recast), OJ 2012, L 351/1. The Regulation will be referred to as Brussels I-Regulation (recast). The Regulation applies as of 10 January 2015 (art. 81 Brussels I-Regulation (recast)). Before that date, Council Regulation (EC) 44/2001 of 22 December 2000 on jurisdiction and the recognition and enforcement of judgments in civil and commercial matters, OJ 2001, L 12/1 applied, which contained the same provisions in Articles 15-17.

${ }^{47}$ The declaration is available at http://ec.europa.eu/civiljustice/homepage/homepage_ec_en_declaration.pdf (last visited on 7 August 2015).

${ }^{48}$ CJEU 6 September 2012, case C 190/11, ECLI:EU:C:2012:542 (Mühlleitner/Yusufi), points 35-45; CJEU 17 October 2013, case C-218/12, ECLI:EU:C:2013:666 (Emrek/Sabranovic), point 25.

${ }^{49}$ See Article 19 Brussels I-Regulation (recast).
} 
Table 6 International jurisdiction clauses

Facebook You will resolve any claim, cause of action or dispute (claim) you have with us arising out of or relating to this Statement or Facebook exclusively in the U.S. District Court for the Northern District of California or a state court located in San Mateo County, and you agree to submit to the personal jurisdiction of such courts for the purpose of litigating all such claims.

Twitter All claims, legal proceedings or litigation arising in connection with the Services will be brought solely in the federal or state courts located in San Francisco County, California, United States, and you consent to the jurisdiction of and venue in such courts and waive any objection as to inconvenient forum.

Google Similarly, if the courts in your country will not permit you to consent to the jurisdiction and venue of the courts in Santa Clara County, California, U.S.A., then your local jurisdiction and venue will apply to such disputes related to these terms. Otherwise, all claims arising out of or relating to these terms or the services will be litigated exclusively in the federal or state courts of Santa Clara County, California, USA, and you and Google consent to personal jurisdiction in those courts.

Dropbox You and Dropbox agree that any judicial proceeding to resolve claims relating to these Terms or the Services will be brought in the federal or state courts of San Francisco County, California, subject to the mandatory arbitration provisions below. Both you and Dropbox consent to venue and personal jurisdiction in such courts.

necessary to determine whether or not such a term would be considered unfair under the Directive - which it undoubtedly would be since even domestic jurisdiction clauses have been found unfair as early as in $2000 .^{50}$

Nevertheless, such clauses still appear in many sets of standard contract terms of online service providers who often offer their services to consumers of more than one Member State (Table 6).

The standard terms of Facebook, ${ }^{51}$ Dropbox, ${ }^{52}$ and Twitter $^{53}$ include a jurisdiction clause awarding exclusive jurisdiction to US federal courts or state courts in California. These terms are clearly contrary to the above-described provisions of the Brussels I-Regulation (recast) and would therefore be found unfair and any competent consumer organization or public authority could challenge them without much difficulty (Rustad and Onufrio 2012, pp. 1126-1127; Wauters et al. 2014b, p. 24). The standard terms of Google ${ }^{54}$ also foresee adjudication by California courts but provide that "if the courts in your country will not permit you to consent to the jurisdiction and venue of the courts in Santa Clara County, California, U.S.A., then your local jurisdiction and venue will apply to such disputes related to these terms." One could argue that since this term, which evidently is not drafted in clear and intelligible language, in itself does not take away the protection offered by the Brussels I-Regulation (recast) and, therefore, does not lead to a derogation of the law, it would be acceptable. However, as a typical consumer would not know, on the basis of this term, that she is not required by this clause to file a claim in a California court but may do so in a court of her own country, the clause may, nevertheless, lead consumers to abstain from starting legal proceedings and as such be considered unfair (Bradshaw et al. 2011, p. 200; Faure and Luth 2011, p. 353). In

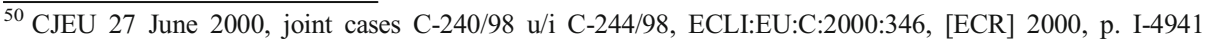
(Océano).

51 Article 15.1 of the Statement of Rights and Responsibilities.

52 See the Terms of Service Dropbox under the heading "Resolving Disputes."

53 Article 12 under B of the Terms of Service.

${ }^{54}$ Google Terms of Service under the heading "About these Terms."
} 
addition, it is uncertain whether, if Google would bring a case against a consumer before a California court, that court would recognize and accept that under the Brussels I-Regulation (recast) the claim must be brought before a court in the country where the consumer lives and declare itself to be incompetent to hear the case. This would mean that such a term is effective after all even though it is contrary to mandatory European consumer law. Therefore, we believe that also the term applied by Google is unfair within the meaning of Article 3 of the Unfair Contract Terms Directive, but recognize that a court may decide otherwise with regard to this clause. This is not likely to be the case with regard to the terms used by Facebook, Twitter, and Dropbox since their terms are clearly contrary to the international jurisdiction rules of the Brussels I-Regulation (recast).

\section{Choice-of-Law Clauses}

Article 3, paragraph 1, of the Rome I-Regulation ${ }^{55}$ sets out that the parties to a contract may choose the law applicable to their contract provided that the choice is made

expressly or clearly demonstrated by the terms of the contract or the circumstances of the case.

This could suggest that a choice-of-law clause included in standard contract terms would not suffice to prescribe a valid choice for the applicable law, unless the trader has specifically drawn the consumer's attention to the term, e.g., by indicating that a choice-of-law clause is included in the standard contract terms. According to Articles 3, paragraph 5, and 10 Rome I-Regulation, the existence and the validity of the consumer's consent to a choice-of-law clause is to be decided on the basis of the chosen law. This implies that the consent may be void or voided under the chosen applicable law in cases of, for instance, duress, fraud, or other vices of consent, but also by virtue of the rules on the incorporation of standard terms or those on unfair contract terms.

Where the parties have not made a valid choice-of-law, Article 4 Rome I-Regulation provides that a contract for the sale of goods or the provision of services is governed by the law of the seller's or service provider's habitual residence. However, Article 6, paragraph 1, Rome I-Regulation determines that a contract concluded by a consumer with a trader is governed by the law of the place where the consumer lives, provided that

(a) The professional pursues its commercial or professional activities in the country where the consumer has her habitual residence or directs such activities to that country or to several countries including that country, and

(b) The contract falls within the scope of such activities.

Paragraph 2 adds that the parties may, nevertheless, choose another law in accordance with Article 3 of the Rome I-Regulation, but such choice may not deprive the consumer of the protection of the mandatory law of the consumer's place of residence.

The criteria listed in Article 6, paragraph 1, of the Rome I-Regulation are the same as those that are listed in Article 17 of the Brussels I-Regulation (recast) (Rustad and Onufrio 2012, p.

${ }^{55}$ Regulation (EC) No 593/2008 of the European Parliament and of the Council of 17 June 2008 on the law applicable to contractual obligations (Rome I), OJ 2008, L 177/6. 
Table 7 Choice-of-law clauses

Facebook The laws of the State of California will govern this Statement, as well as any claim that might arise between you and us, without regard to conflict of law provisions.

Twitter These Terms and any action related thereto will be governed by the laws of the State of California without regard to or application of its conflict of law provisions or your state or country of residence.

Google The courts in some countries will not apply California law to some types of disputes. If you reside in one of those countries, then where California law is excluded from applying, your country's laws will apply to such disputes related to these terms. Otherwise, you agree that the laws of California, U.S.A., excluding California's choice of law rules, will apply to any disputes arising out of or relating to these terms or the Services.

Dropbox These Terms will be governed by California law except for its conflicts of laws principles, unless otherwise required by a mandatory law of any other jurisdiction.

1130). In this respect, it is not surprising that recital (7) of the preamble to the Rome I-Regulation states that the substantive scope and the provisions of that regulation should be consistent with that of the (former) Brussels I-Regulation, whereas recital (24) explicitly indicates that the concept of "directed activity" in Article 6, paragraph 1, of the Rome I-Regulation should be interpreted in the same manner as in (then) Article 15, paragraph 1, of the Brussels I-Regulation.

Given the close relationship between the Brussels I-Regulation and the Rome I-Regulation, where the requirements of Articles 17-19 Brussels I-Regulation (recast) are met, this entails that also the requirements of Article 6 of the Rome I-Regulation are met. This implies that choice-of-law clauses are valid in so far as they are incorporated into the contract by a valid expression of consent by the consumer. However, they cannot lead to the result that the consumer is deprived of the protection offered by the Unfair Contract Terms Directive, nor is she excluded from the protection of the mandatory law of the consumer's place of residence in so far as she demonstrates that the trader had directed his activities to the country where the consumer has her domicile and the contract pertains to such activities.

Moreover, even if a choice-of-law clause in itself is incorporated validly into the contract with a consumer, this clause could still be considered unfair under Article 3 of the Unfair Contract Terms Directive. This could occur if it gives the false impression to the consumer that her national law is irrelevant for the dispute she has with the online service provider, for instance by falsely claiming that the law of the country where the service provide is located is applicable with the exclusion of any other law. The result of such a clause would be that the consumer is not able to ascertain what her rights and obligations under the contract are, as she is made to believe that her contract is governed by a foreign law with which she will typically not be familiar with. Such a clause would likely violate the principle of good faith and distort the balance between the parties' rights and obligation to the detriment of the consumer.

Clearly, not all sets of online standard terms will meet the requirements set by European law

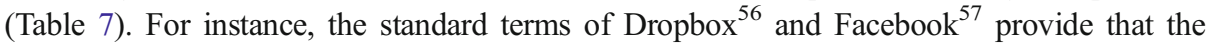
contract is governed by California law. ${ }^{58}$ Twitter $^{59}$ goes much further by stating that the terms

\footnotetext{
${ }^{56}$ See the Terms of Service of Dropbox under the heading "Controlling Law."

57 Article 15.1 of the Statement of Rights and Responsibilities.

${ }^{58}$ Interestingly, Facebook makes an exception for consumers living in Germany, where German law is declared to be the applicable law. See Article 16.3 of the Statement of Rights and Responsibilities linking to special terms for German consumers, and point 5 of those terms; the special terms are available online at https://www. facebook.com/terms/provisions/german/index.php (last visited on 7 August 2015).

59 Article 12 under B of the Terms of Service.
} 
are regulated by California law "without regard to or application of (...) your state or country of residence," which apparently intends (in badly drafted text, we might add) to explicitly exclude the application of the law of the consumer's domicile. Therefore, the standard terms and conditions of these online service providers violate the Rome I-Regulation and will be seen as unfair.

The most decent set of terms of these four major internationally operating online service providers appears to have been used by Google. ${ }^{60}$ Again, a choice for California law is made, but it is also indicated that "the courts in some countries will not apply California law to some types of disputes. If you reside in one of those countries, then where California law is excluded from applying, your country's laws will apply to such disputes related to these terms." One could argue that since the term does not take away the protection offered by the Rome I-Regulation, it would not be unfair. However, as a typical consumer would not know, on the basis of this term, that in fact her own law is the applicable law, the clause may, nevertheless, lead consumers to abstain from starting legal proceedings. They may, unsurprisingly, not be able to properly assess their chances of winning the case due to their ignorance of California law or be afraid of the costs involved in adjudicating the case on the basis of a foreign law (whether or not also in a foreign court). There is therefore a risk that on the basis of such considerations, consumers could be withheld from bringing a case before their national court or from defending their position against a claim brought by Google. We, therefore, believe that also the term applied by Google is unfair within the meaning of Article 3 of the Unfair Contract Terms Directive but recognizes that a court may decide otherwise with regard to this clause.

\section{Transparency}

Leaving substantive complaints pertaining to other clauses used by online service providers aside, the issue of their lack of transparency could be raised as well. While it is well known that internet users often do not read any disclosures, contractual terms, etc. provided to them online, it remains paramount to draw the user's attention to contractual terms and conditions parallel to drafting them in a way that would facilitate user's reading and understanding of these terms (Leone 2014, pp. 322-323; Wauters et al. 2014a, p. 10; Wilhelmsson 2006, p. 55). This would require online service providers to draft these terms in a legible, clear, and transparent way as well as to make them prominently visible on their websites.

Article 5 of the Directive requires contract terms to be

drafted in plain, intelligible language. Where there is doubt about the meaning of a term, the interpretation most favourable to the consumer shall prevail.

This provision obliges online service providers to use transparent contract terms; however, the standard for this transparency has not been further defined in the Directive. Moreover, the only sanction explicitly provided for the breach of the transparency requirement is the contra proferentem interpretation rule (Armbrüster

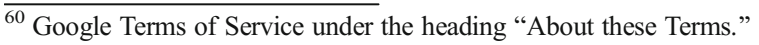


2008, pp. 168-169; Leone 2014, pp. 323-324). However, in the recent Kásler-case, the CJEU clarified that where a term is non-transparent, a national court needs to consider this when it assesses the term's unfairness. ${ }^{61}$ That is to say, national courts should check whether the lack of transparency is contrary to good faith and creates a significant imbalance between the parties' rights and obligations to the detriment of the consumer.

In addition, paragraph 1 under (i) of Annex I to the Directive classifies as potentially unfair a clause

irrevocably binding the consumer to terms with which he had no real opportunity of becoming acquainted before the conclusion of the contract.

The CJEU has not yet applied this provision with respect to non-transparent contractual terms and conditions, but such an interpretation thereof is feasible. Notwithstanding the fact that the lack of transparency may sometimes render a term to be unfair as it may mislead consumers with regard to their rights and obligations, ${ }^{62}$ transparency also has a more independent role to play. That is to say, it may enable consumers to actually become aware of their rights and obligations, both prior to and post the moment of the contract's conclusion (Armbrüster 2008, pp. 167-168; Leone 2014, pp. 322-323; Micklitz 2014, p. 143, 145; Micklitz and Reich 2014, p. 788; Rott 2013, pp. 733-734). Therefore, it could be considered that consumers should not be bound by contractual terms, which are hard to access, read, and understand for an average consumer. Hindering access to contractual terms, e.g., through the use of many hyperlinks leading consumers from one website to another and yet another, ${ }^{63}$ or drafting contractual terms in a technical, hard-to-grasp language could be seen as not providing consumers with a "real opportunity" to read the contract (Girot 2001, pp. 318-319, 322; Micklitz 2014, p. 143). In our view, where this is the case, the transparency principle is breached and a term should either be considered as not having been validly incorporated into the contract or as unfair.

Similarly, in order for the consumer to be able to ascertain her rights and obligations under the contract, the standard contract terms must be drafted in a language the consumer is or should be able to understand (Girot 2001, pp. 327329; Micklitz 2014, p. 143). In our view, the consumer may expect the terms to be drafted in either her mother tongue or the language in which the contract has been concluded. In the latter case, the consumer knowingly concluded a contract in another language than her mother's tongue and may be expected to properly master that language or to have accepted the consequences of not being able to properly understand that language. However, in our view, the transparency principle is breached where the standard contract terms are neither drafted in the consumer's mother tongue nor in the language in which the contract is concluded. National courts should

\footnotetext{
${ }^{61}$ See CJEU 30 April 2014, case C-26/13, ECLI:EU:C:2014:282 (Kásler and Káslerné Rábai/OTP Jelzálogbank Zrt), points $73-74$.

62 The clauses on limitation of or exemption from liability, and the jurisdiction and choice-of-law clauses are examples thereof since they may convince consumers that the service provider is not liable and legal action is to be taken in the USA under US law.

${ }^{63}$ For instance, Facebook's Data Use Policy consists of no less than 6 separate documents, which moreover also refer the consumer back and forth to her privacy and notifications settings, the US Department of Commerce's Safe Harbor website, Facebook's help page, its security page, and the Site Governance Page.
} 
consider such terms either as not having been validly incorporated into the contract or as unfair.

\section{Conclusions}

On the basis of our research, we have identified several types of contractual terms that international online service providers provide to consumers, which would be unlikely to pass the Directive's unfairness test. We believe that the contractual terms mentioned in this paper should be challenged in court as well as that they should be tested ex officio by national courts. Moreover, we suggest that national courts refer more questions to the CJEU for a prejudicial ruling on the interpretation of the unfairness test with regard to the contract terms discussed in this paper, especially pertaining to the role of the Annex therein. If the CJEU confirmed the unfairness of these terms, this would then have a harmonizing effect on the online service providers' practices with regard to drafting online contractual terms. For example, it would improve legal certainty to ascertain whether traders have the same obligations when they draft contract terms allowing them to change the contract's price and when they draft contract terms allowing them to change other contractual terms.

However, as it seems unlikely that individual consumers will in fact bring a claim against an online service provider for what many consumers still perceive to be "free" services, we believe there is a task here for consumer authorities and other public bodies, and for consumer organizations. In this respect, it is important to realize that under European Union law, where consumer protection rules are infringed, a consumer organization or a consumer authority is normally allowed to bring a claim against the infringing trader before its own courts under (now) Article 7, paragraph 2, of the Brussels I-Regulation (recast), as the Court of Justice of the European Union explained in the Henkel case, provided that the trader targets at least also consumers domiciled in that country. ${ }^{64}$ In other words, would an individual consumer be able to bring a claim against the trader before her own court under Articles 17-19 of the Brussels IRegulation (recast), then the consumer organization or the consumer authority representing the interests of such a consumer would be able to bring the trader before that same court under Article 7, paragraph 2, of the Regulation. Moreover, it seems likely that the Rome IIRegulation $^{65}$ will be applicable as regards the determination of the law applicable to such a case. ${ }^{66}$ If this is indeed the case, the law applicable would be the law of the country where the consumer whose interests are being represented has her habitual residence, which implies that the consumer organization or the consumer authority would normally be allowed to bring the claim in its own country and under its own law. ${ }^{67}$ In this respect, the international character of these online services need not stand in the way of effective collective enforcement of EU consumer law (see Djurovic 2013, p. 254).

\footnotetext{
${ }^{64}$ CJEU 1 October 2002, case C-167/00, ECLI:EU:C:2002:555 (Verein für Konsumenteninformation/Henkel), points $37-48$.

${ }^{65}$ Regulation (EC) No 864/2007 of the European Parliament and of the Council of 11 July 2007 on the law applicable to non-contractual obligations, OJ 2007, L 199/40.

${ }^{66}$ On 27 April 2015 the highest Austrian court, the Oberster Gerichtshof, has referred a question for prejudicial ruling on this point; the case is currently pending, see case C-191/15 (Verein für Konsumenteninformation/ Amazon EU).

${ }^{67}$ See in particular Articles 2, paragraph 2, and 4, paragraphs 1 and 2, Rome II-Regulation, in accordance with recital (7) to the Regulation read in conjunction with the Brussels I- and Rome I-Regulations.
} 
Open Access This article is distributed under the terms of the Creative Commons Attribution 4.0 International License (http://creativecommons.org/licenses/by/4.0/), which permits unrestricted use, distribution, and reproduction in any medium, provided you give appropriate credit to the original author(s) and the source, provide a link to the Creative Commons license, and indicate if changes were made.

\section{References}

Armbrüster, C. H. (2008). Standard contract terms and information rules. In H. Collins (Ed.), Standard contract terms in Europe: A basis for and a challenge to European contract law (pp. 163-175). Alphen aan den Rijn: Kluwer Law International.

Bradshaw, S., Millard, C., \& Walden, I. (2011). Contracts for clouds: Comparison and analysis of the terms and conditions of cloud computing services. International Journal of Law and Information Technology, 19, 187-223.

Cordera, M. (2001). E-consumer protection: A comparative analysis of EU and US consumer protection on the internet. Rutgers Computer \& Technology Law Journal, 27, 231-263.

Djurovic, M. (2013). The apple case: the commencement of Pan-European battle against unfair commercial practices. European Review of Contract Law, 9, 253-266.

Faure, M., \& Luth, H. (2011). Behavioural economics in unfair contract terms. Journal of Consumer Policy, 34, $337-359$.

Girot, C. (2001). User protection in IT contracts: A comparative study of the protection of the user against defective performance in information technology. The Hague: Kluwer Law International.

Helberger, N., Guibault, L., Loos, M., Mak, C., Pessers, L., \& van der Sloot, B. (2013). Digital consumers and the law, towards a cohesive European framework. Alphen aan den Rijn: Kluwer Law International.

Hoofnagle, C. J., \& Whittington, J. (2014). Free: Accounting for the costs of the internet's most popular price. UCLA Law Review, 61, 606-670.

Keirsbilck, B. (2013). The erga omnes effect of the finding of an unfair contract term: Nemzeti. Common Market Law Review, 50, 1467-1478.

Leone, C. (2014). Transparency revisited - on the role of information in the recent case-law of the CJEU. European Review of Contract Law, 10, 312-325.

Leydon, CH. (2013). What happened when Facebook disabled my account. The Next Web, 15.01.2013, available online at $<<$ http://thenextweb.com/facebook/2013/01/15/what-happened-when-facebook-disabled-myaccount $/>$.

Loos, M., Helberger, N., Guibault, L., \& Mak, C. (2011). The regulation of digital content contracts in the optional instrument of contract law. European Review of Private Law, 6, 729-758.

Micklitz, H.-W. (2010). Reforming European unfair terms legislation in consumer contracts. European Review of Contract Law, 4, 347-383.

Micklitz, H.-W. (2014). Unfair terms in consumer contracts. In N. Reich, H.-W. Micklitz, P. Rott, \& K. Tonner (Eds.), European consumer law (pp. 125-164). Antwerp: Intersentia.

Micklitz, H.-W., \& Reich, N. (2014). The court and sleeping beauty: The revival of the Unfair Contract Terms Directive (UCTD). Common Market Law Review, 51, 771-808.

Moses, A. (2008). Banned for keeps on Facebook for odd name. The Sydney Morning Herald, 25.09.2008, available online at << http:/www.smh.com.au/news/biztech/banned-for-keeps-on-facebook-for-odd-name/ 2008/09/25/1222217399252.html >>.

Reich, N., \& Micklitz, H.-W. (2014). Economic law, consumer interests, and EU integration. In N. Reich, H.-W. Micklitz, P. Rott, \& K. Tonner (Eds.), European consumer law (pp. 1-65). Antwerp: Intersentia.

Rott, P. (2013). The adjustment of long-term supply contracts: Experience from German gas price case law. European Review of Private Law, 3, 717-746.

Rustad, M., \& Onufrio, M. V. (2012). Reconceptualizing consumer terms of use for a globalized knowledge economy. University of Pennsylvania Journal of Business Law, 14, 1085-1190.

Tenreiro, M. (1995). The community directive on unfair terms and national legal systems. The principle of good faith and remedies for unfair terms. European Review of Private Law, 3, 273-284.

Terryn, E. (2013). Unfair contract terms - Statutory provisions, price increase terms and the role of the CJEU. In E. Terryn, G. Straetmans, \& V. Colaert (Eds.), Landmark cases of EU consumer law (pp. 677-700). Antwerp: Intersentia.

Tonner, K. (2014). The consumer rights directive and its impact on internet and other distance consumer contracts. In N. Reich, H.-W. Micklitz, P. Rott, \& K. Tonner (Eds.), European consumer law (pp. 393414). Antwerp: Intersentia. 
Trstenjak, V. (2013). Procedural aspects of European consumer protection law and the case law of the CJEU. European Review of Private Law, 2, 451-478.

Wauters, E., Donoso, V., \& Lievens, E. (2014a). Optimizing transparency for users in social networking sites. Information, 16, 8-23.

Wauters, E., Lievens, E., \& Valcke, P. (2014). Towards a better protection of social media users: A legal perspective on the terms of use of social networking sites. International Journal of Law and Information Technology, 0, 1-41.

Wilhelmsson, T. (2006). Cooperation and competition regarding standard contract terms in consumer contracts. European Business Law Review, 1, 49-72. 